\title{
Risk of Shareholders Contributing Land Management Right as Capital under Separation of Land Ownership, Contract Right and Management Right and the Risk Avoidance
}

\author{
Chao Zhang \\ School of Law \\ Sichuan University \\ Chengdu, China
}

\begin{abstract}
The Separation of Three Rights is the system of land rights three-way separation is the system of land rights separating land ownership, contract right and management right, which aims to increase farmers' benefit of high value-added industries based on land by participating in profit, improve land use efficiency and revitalize the rural economy. However, contributing land management right as capital may bring some risks to the shareholder in implementation. This paper tries to analyze the shareholder's risk from perspectives of company construction and compensation of land expropriation, and propose laws and implementing mechanism to improve the existing situation of contributing land management right as capital. Protecting the shareholder from risk can better give play to the Separation of Three Rights.
\end{abstract}

Keywords-land management right; joint-stock company; shareholder risk

\section{INTRODUCTION}

The Third Plenary Session of the 18th Central Committee of the Communist Party of China (CPC) adopted the "Decision on Several Important Issues Concerning the Comprehensive Deepening of Reform" (hereinafter referred to as the "Decision") and put forward the separation of contract right and management right, to establish the system of rural land right system separating ownership, contract right and management right. Later, the Ministry of Agriculture began pilot projects of contributing land management right as capital in seven areas from March 2015, and proposed to take the direct registration of company with land management right as the key to the next step of pilot project based on summarizing the experience ${ }^{1}$. In the guidance of contributing land management right as capital in 2015, the Ministry of Agriculture mentioned three contribution modes, including the modes in which farmers directly contribute to enterprises with land management right as capital, farmers contribute to cooperatives and then cooperatives contribute to enterprises,

1 Source : government information on the website of the Ministry of Agriculture, website:

http://www.moa.gov.cn/zwllm/zwdt/201611/t20161121_5370292.htm. and farmers contribute to cooperatives with land management right, as well as enterprises and individuals with other elements, etc., which intend to enable farmers to obtain benefit of high value-added industries based on land by sharing profits according to contributions, and improve land use rate and integrative development of the first, second and third industry in rural areas. ${ }^{2}$

In theory and experiment, contributing land management right under the Separation of Three Rights is more applicable to the revitalization of land use right than contributing land contracted management right under the dual structure. The reason for such difference is related to the construction and nature of the two rights themselves. First of all, in terms of the nature, currently there is study of the land management right thinking that the land management right itself has more nature of property right rather than the nature of personal right such as the membership right in collective economy. Through the expansion of the land use right, it can create usufruct ${ }^{3}$, and

\footnotetext{
2 "Plan for National Agricultural Products Processing Industry and Integrative Development of First, Second and Third Industry in Rural Areas (2016 2020)", issued by the Ministry of Agriculture on November 14, 2016, website http://www.moa.gov.cn/sjzz/qiyeju/ Dongtai / 201611 t20161130 5383074.htm."Opinions on Perfecting the "Opinions Concerning Improvement Separation of Rural Land Ownership and Contract Right", issued by the General Office of the CPC Central Committee in October 2001, website:

http://www.moa.gov.cn/zwllm/zcfg/flfg/201611/t20161101_5345436. Htm. "Notice of the General Office of the Ministry of Agriculture on Organizing the Application of Contributing Land Management Right as Capital and the Development of Agricultural Industrialization Management Pilot Scheme" (NONG BAN JING [2015] No. 19), issued by the Ministry of Agriculture on March 19, 2015.

${ }^{3}$ Cai Lidong, Jiang Nan: "The Law Structure of Separating Contract Right and Management Right", "Law Research", 2015-3, Page 31-46. it is mentioned in the paper that the land management right is another usufruct taking the land contracted management right as the object but different from it, whose usufruct object is the right rather than movable property and real estate. It breaks through the restriction of "Property Law", and belongs to innovative right. Such innovation is based on the exclusiveness of the real right firstly, that two same usufructs cannot exist on the same thing, secondly, the creation of land management right intended to separate the property right in the land use right, and represents time order with the existence of contracted management right as a more flexible transfer right. See "Property
} 
enable it to better reflect the market characteristics with autonomy of will, such as the achievement of equality and non-identity, independence, exclusivity and complete disposability. Secondly, in terms of the scope of application, due to the limitation of membership right ${ }^{4}$, the contribution mode of the land contracted management right distinguishes the transfer scope of the family contractors and fourwasteland contractors ${ }^{5}$ : one needs to transfer within the collective economic organization, and the other can expand the scope, while the land management right can integrate the two scopes in the preparation conditions.

Contribution of land management right guide to the development of large-scale intensive agricultural industry, in which resource integration through corporate system can deploy production resources, increase the additional value of products, control the market trend and combine agricultural science and technology research and production to a greater extent. However, the corporate system will also speed up the right transfer, broaden market access, and make farmers farther away from the actual control of the land. The individual farmers contribute both the land contracted management right as well as land management right as capital benefit while taking more risk in the market distribution. This paper tries to discuss this.

\section{THE SHAREHOLDERS' RISK UNDER THE CONSTRUCTION OF JOINT-STOCK COMPANY}

\section{A. Contradiction between Equity Inheritance and Land Contracted Management Right}

China's "Rural Land Contract Law" divides contracts into family contract and other forms of contract. In the family contract, because the contract right is based on the membership right of collective economic organizations, which requires the land to be reverted to the collectivity for contract after the death of the land contractor, the land is maintained within the collective economic organization with controllable inheritance, and some scholars think this can be considered a general inheritance ${ }^{6}$, also a limited inheritance ${ }^{7}$. There has not been clear stipulation for inheritance and transfer of the contribution of land management right as capital in the existing law, and it is only mentioned in the policy documents concerning pilot that they shall be recognized by the collective economic organizations or filed on the basis of adhering to the collective land ownership". In the "Company Law", after the death of natural person shareholders, their legal heir may inherit the shareholder's qualification, and the

Law Research", Wang Liming, China Renmin University Press, 2013 edition, Page 10.

${ }^{4}$ Yang Suiquan, Li Juan, Wang Xu: "Legal and Economic Analysis on Homestead Circulation", "Rural Economy", 2015-12, Page 9-14.

${ }^{5} \mathrm{Li}$ Yanrong, Li Yanke: "Discussion on the "Four-wasteland" contracted management right Transfer", "Law Science Magazine". 2011-5, Page 38-41.

${ }^{6}$ Chen Su: "Inheritance Mechanism of the Land contracted management right and Its Interpretation of Dialectic", "Tsinghua Law Journal". 2016-3, Page 57-71.

${ }^{7}$ Wang Tingyong, Yang Suiquan: "Study on the Limited Inheritance System of Rural Land contracted management right - and the Reference significance of French Rural Land Inheritance", "Truth Seeking". 2015-8, Page 90-96.

${ }^{8}$ See Note 2 . shareholder's transfer of shares to the person other than shareholders should be agreed by other shareholders, or it shall be inherited in accordance with the articles of association, but the inheritance or transfer shall not break the legal conditions for the establishment of limited liability companies.

When the farmers who have obtained the land contracted management right in the collective economic organizations contribute the land management right as capital in the company and then die, the contracted management right and the management right of this land will be separated on the same oblige. The land contracted management right is reverted to collective economic organizations to be contracted separately, and the land management right may be obtained by the successor of the natural person through the inheritance procedure as a contributed capital. Therefore, can the person who has the new contracted management right of this land after new contract obtain the land management or contribute it as capital based on this? Is the inheritance of equity affected or invalidated by the change in the land contracted management right as its basis?

Under the current theory, because the ownership, the use right and the management right are split but not completely fragmented, if land management right is considered as usufruct, its effectiveness can not be divorced from land contracted management right as the right object. On the other hand, it's mentioned in the government's guidance that the transfer of land management rights still needs to respect the views of collective economic organizations and filing is proposed, under such mechanism, issues such as whether the law needs to be distinguished from ordinary corporate equity inheritance on the inheritance of the land management right, and whether the legal mandatory provisions will affect the company's will need further legislative solution.

\section{B. Shareholders' Risk in Corporate Personality Denial System and Shareholder Representative Lawsuit}

The equity system is based on the shareholder's contribution in the corporate system, which restricts the shareholders' liability to the scope of contribution, and raises capital through joint venture to maintain the operation. Such institutional framework protects the interests of shareholders, in which the company is responsible for the creditors with its own capital, and shareholders are responsible for the company's credit and debt within the limit of shares. But the interests of the controlling shareholder, the corporate operator and the creditor are not always consistent, when there is a conflict among them, in order to protect the legitimate rights and interests of the oblige based on the articles of association and legal framework and maintain the company operation as much as possible, the law allows creditors and individual shareholders to break through the company personality and shareholder protection under certain conditions, two of which are corporate personality denial system and shareholder representative lawsuit system. Under such breakthrough, some shareholders' interests may be challenged.

The corporate personality denial system is intended to give the court or arbitration institution the right to order the 
controlling shareholder to fulfill the legal obligations and take legal responsibility directly to the company' s creditors when the controlling shareholder violates the principle of good faith, abuses the legal person's qualification or the treatment of shareholder limited liability in order to evade the legal obligation or responsibility, and causes severe damage to the creditors' interests, so as to protect the legitimate interests of creditors ${ }^{9}$. With contribution of the land management right as capital in the company, the land operators become shareholders, and shareholders' contributed property and personal property are under isolated protection of the company, but when the shareholders abuse the power and damage the interests of creditors, they will lose the isolated protection of the company.

Shareholder representative lawsuit is a lawsuit mechanism in which the legally qualified shareholder has the right to file a lawsuit in his/her own name on behalf of the company when a company is slack to investigate and affix the responsibility of the operator who damages the interests of the company in order to safeguard the interests of the company, and the compensation is attributable to the company ${ }^{10}$. In the transfer of contributing the land management right as capital in the company, the company is established with the land management right holder contributing the management right as capital, due to the large number of shareholders, the person actually responsible for the operation of the company cannot fully express the will of all shareholders, and his/her operating policy will not be agreed by all shareholders, so the loss of the company is common. In this case, under the framework of the company law, if it reaches a certain amount provided by law to bring shareholder representative lawsuit, it may also cause loss of interests to another part of the shareholders.

Generally speaking, shareholders who contribute the land management right as capital are ordinary farmers, and do not have other personal property to bear the credit and debt risks in the operation of the company, but there is no basis for the mechanism of gaining dividends without bearing risks. Whether the interest protection of shareholders who contribute the land management right as capital and the shareholders of general joint-stock companies can be put under the same market theory is an important problem to be solved in the experiment.

\section{Conflict between the Right Setting of Management Right and Company Capital Principle}

In the trial of rural land reform, the mortgage of land management right emerged due to the mortgage contract between the mortgagee and the mortgagor (the land management right holder). The mortgage of the land management right embodies the agreement between the mortgagee and the mortgagor. In the existing system experiment, the proposal of mortgage of the land management right can be established based on the following conditions ${ }^{11}$ :

\footnotetext{
${ }^{9}$ Liu Junhai, "Modern Company Law", Law Press, June 2011, Page 292-299.

${ }^{10}$ Ibid, Page 543-554.

11 Gao Shengping: "Construction of the mortgage of management of contracted land - and comment on the supporting reform pilot model of Chongqing urban and rural integration", "Studies in Law and Business".
}

obtain the "Certificate of Rural Land Management Right" in accordance with the law, and those who guarantee mortgages for the transferee of rural land transfer must also have a complete "transfer contract for rural land contract management rights"; the written proof that the contractissuing party to which the collateral belongs agrees to mortgage the land contract management right; those who obtain the mortgage of land use right through subcontracting, rental, circulation shall have the written proof that the contractor agrees to mortgage; the mortgage agreement reached by the mortgagor and mortgagee. On the other hand, under the principle of company law, the company must comply with the principle of capital determination, capital maintenance and capital invariance. When the land management right is contributed as capital in the company, the shareholder shall ensure that the land management right is not defective as the contributed right, namely ensure the contribution.

In the current experiment, how to determine ownership and avoid risk in system setting still needs to exploration. The pricing and capital verification of contribution of the land management right cannot guarantee that the right is flawless because it does not compulsively require the publicity and registration. Government guidance proposes that the management subject needs to get the written consent of the contracting farmers or their entrusted agents and put on records to all the farmers in writing to re-circulate the land management right or set mortgage according to the law.

"Property Law" develops rules for different types of property mortgage based on the classification of mortgaged property, and proposes property rules such as registration effectiveness and registration antagonism for the registration issue. As the object of the mortgage, as a new usufruct, the land management right does not belong to any kind of property or right listed in the existing property law, so it falls into "other property rules" when in search of conditions for setting mortgage of the land management right, namely beyond the scope of provisions of law. Some studies have found $^{12}$ that the method of analogy explanation can be taken to find a reasonable rule. The land management right is similar to the situation of "obtaining the management right of lands such as wasteland through tender, auction, public consultation and other means" provided in Article 180.1.3 of the "Property Law", in both of which the agricultural management subjects obtain the management right by signing the management contract with the land contracted management holder or collective economic organization in marketing mode, different from the land contracted management right obtained by family contracting. "Property Law" adopts registration effectiveness for the mortgage of the above-mentioned land contracted management right, and the mortgage of the land management right may also adopt registration effectiveness through analogy. Under this inference, through the establishment of registration effectiveness, when the land management right is contributed as capital, the capital verification can be completed more easily by registration.

\footnotetext{
2016-1. Page 3-12

12 Ibid.
} 


\section{Shareholder's Risk Brought by the Company Change and Increased Equity Transfer}

The corporate system makes the scope of land use break through the collective economic organizations and able to enter the market for multiple transfers. When the land transfer is increased, or when the company operator realizes capital appreciation through capital operation such as equity transfer and company change, the cost of land production increases, the cost premium affects the dividends of shareholders, or the shareholders as the land contracted management holder keep more and more away from the control of land, the conflict between the land management right and the land contracted management right frequently occurs on the individual shareholder, and thus affects the company's overall operation and development.

According to the current government guidance and experimental pilot system construction, the transfer of land contracted management right needs to obtain the consent of the original contractor and the contract letting party, and the transfer of the land management right in a limited liability company needs to be agreed by the shareholders. However, after the equity has been transferred many times, the land contracted management right holder has been separated from the shareholder after the several transfers, thus both the restricted meaning agreed by him/her and the meaning of land control have been weakened. Whether it is necessary to set other mechanisms to strengthen the control of the contractor on the equity transfer of this type of company can be further discussed.

\section{SHAREHOLDERS' RISK IN THE LAND EXPROPRIATION COMPENSATION}

In the "Land Management Law" and the pilots for Separation of Three Rights, the government's "Opinions on the improvement of separation of the rural land ownership, contract right and management right" ${ }^{13}$ stipulates that if the transferred land is expropriated, the expropriation compensation belongs to the collective economic organizations with the land ownership, the attribution of the compensation for attachments or green crops on the land should be determined according to the agreement of the transfer contract. But the decision for expropriation compensation, value assessment procedures and compensation distribution are still lacked. In the land acquisition after the land management right is contributed to a company, the company joins in expropriation operation mechanism as the new subject, while the land management right in the form of equity becomes the new object, and the market value evaluation and equity acquisition mode may introduce the market price negotiation mechanism to the expropriation procedures. However, currently, it is mainly to achieve the public interest dominated by administrative machinery, and the collective economic organizations expropriate and compensated as the subject of right, ignoring the individual member's rights and interests, which may bring risks to the stockholders' equity such as administrative compulsory withdrawal and loss of equity interests.

\footnotetext{
${ }^{13}$ See note 2
}

In the construction of the new mechanism, it is proposed that the expropriation compensation mechanism suitable for the transfer of the land management right should be established on the legislative concept of "reducing public sector and raising private sector", dilute the public law element of administrative power, strengthen the private law element of property rights, and adopt the principle of collective participation and its system construction, guide the fair and just development of expropriation ${ }^{14}$. This system design requires the participation of the collective members. In the whole process of collective land expropriation, the members should fully and virtually intervene in all links from the recognition of public interest, the design of compensation resettlement plan, the distribution of land compensation payment to dispute settlement procedure and judicial relief mechanism, and exercise the speaking right of collective members on expropriation.

The system construction on this basis may have the following characteristics: Firstly, it classifies public interests, helps to define the boundaries of public interests, and establish the auxiliary mechanism to monitor the sustainability of achieving public interests. Secondly, it sets prepositive procedures of compensation negotiation, introduces comprehensive factors such as the equity market value, average capacity value of land area and the positive value of public interests to balanced consideration of compensation value. Thirdly, it sets expropriation decisions and judicial remedies in the link of expropriation compensation for the expropriated and interested parties. Fourthly, it sets different expropriation decisions and compensation procedures for different rights, and introduces the market economy consultation mechanism for the property rights involved in the expropriation, or sets up preemptive right of the government; it improves the social security system for the personal rights, or sets priority development right for collective members based on the public interest, to supplement the existing compensation for property and property rights.

\section{CONCLUSION}

The land management right is a new right of the system experiment, and its own nature, establishment condition, way of exercising, legal consequence, as well as fusion and connection with the relevant legal systems are not determined, so it needs to comprehensively design from the construction of legal system, the process of legal implementation, and the conflict integration with other systems and theories, to avoid various risks arising from the new usufruct. First of all, it needs to improve and reconstruct the relevant legal system, establish the sustainable risk control mechanism of the legal system for innovation and development model. Secondly, it needs to adjust the traditional legal basic concept, try to break through the traditional theory in the system experiment, and innovate experimental theory. Finally, it needs to start from the design of multiple systems, extract the common cause adapted to the new system or mode of operation in the

\footnotetext{
${ }^{14}$ Chen Xiaojun: "Legal reflection and institutional reconstruction of rural collective land expropriation", "China Legal Science". 2012-1. Page 33-44.
} 
selection and adjustment, and establish a reasonable legal system and the implementation mechanism.

\section{REFERENCES}

[1] Cai Lidong, Jiang Nan: "The Law Structure of Separating Contract Right and Management Right", "Law Research", 2015-3.

[2] Yang Suiquan, Li Juan, Wang Xu: "Legal and Economic Analysis on Homestead Circulation", "Rural Economy", 2015-12.

[3] Li Yanrong, Li Yanke: "Discussion on the "Four-wasteland" contracted management right Transfer", "Law Science Magazine". 2011-5.

[4] Chen Su: "Inheritance Mechanism of the Land contracted management right and Its Interpretation of Dialectic", "Tsinghua Law Journal". 20163.

[5] Wang Tingyong, Yang Suiquan: "Study on the Limited Inheritance System of Rural Land contracted management right - and the Reference significance of French Rural Land Inheritance", "Truth Seeking". 2015-

[6] Gao Shengping: "Construction of the mortgage of management of contracted land - and comment on the supporting reform pilot model of Chongqing urban and rural integration", "Studies in Law and Business". 2016-1.

[7] Chen Xiaojun: "Legal reflection and institutional reconstruction of rural collective land expropriation", "China Legal Science". 2012-1.

[8] Wang Liming: "Property Law Research", China Renmin University Press, 2013 edition.

[9] Liu Junhai, "Modern Company Law", Law Press, June 2011. 